\title{
Spinal Cord Stimulation for Patients with Failed Back Surgery Syndrome: A Systematic Review
}

Michael E. Frey, MD1, Laxmaiah Manchikanti, MD², Ramsin M. Benyamin, MD³, David M. Schultz, MD ${ }^{4}$, Howard S. Smith, MD ${ }^{5}$, and Steven P. Cohen, MD 6

From: ${ }^{1}$ Advanced Pain Management and Spine Specialists, Fort Myers, FL; ${ }^{2}$ Pain Management Center of Paducah, Paducah, KY; ${ }^{3}$ Millennium Pain Center, Bloomington, IL; 4Medical Advanced Pain Specialists, Minneapolis, MN; Albany Medical College, Albany, NY; and ${ }^{6}$ Johns

Hopkins School of Medicine, Baltimore, MD

Dr. Frey is with Advanced Pain Management and Spine Specialists, Director of

Interventional Physiatry, Ft. Myers, FL, Assistant Clinical Professor, Adjunct Faculty, Virginia Commonwealth University, Richmond, VA. Dr. Manchikanti is Medical Director of the Pain Management Center of Paducah, Paducah, KY, and Associate Clinical Professor of Anesthesiology and

Perioperative Medicine, University of Louisville, Louisville, KY. Dr. Benyamin

is Medical Director, Millennium Pain Center, Bloomington, IL, Clinical Assistant Professor of Surgery, College of Medicine, University of Illinois, Urbana-Champaign,

IL. Dr. Schultz is the Medical Director and President of Medical Advanced Pain Specialists, Minneapolis, MN. Dr. Smith is

Associate Professor and Academic Director of Pain Management for Albany Medical College, Department of Anesthesiology, Albany, NY. Dr. Cohen is Associate Professor, Department of Anesthesiology and Critical Care Medicine, Pain Management Division, Johns Hopkins School of Medicine,

Baltimore, MD, and Walter Reed Army Medical Center, Washington, DC.

Address correspondence: Michael E. Frey, MD Advanced Pain Management and Spine Specialists PO Box 07400 Fort Myers, FL 33919 E-mail:mfreymd@comcast.net

Disclaimer: Dr. Frey is a paid consultant with Boston Scientific. Dr. Schultz receives funding from Medtronic. Conflict of interest: None.

Manuscript received: $1 / 13 / 2008$ Accepted for publication: 02/08/2009

Free full manuscript: www.painphysicianjournal.com
Background: Failed back surgery syndrome is common in the United States. Management of post lumbar surgery syndrome with multiple modalities includes interventional techniques, resulting in moderate improvement, leaving a proportion of patients in intractable pain. The systematic reviews of long-term benefits and risks of spinal cord stimulation (SCS) for patients with failed back surgery syndrome showed limited to moderate evidence and cost effectiveness. However, with the exponential increase in surgery in the United States, spinal cord implants are also increasing. Thus, the discussion continues with claims of lack of evidence on one hand and escalating increases in utilization on the other hand.

Study Design: A systematic review of SCS in patients with failed back surgery syndrome.

Objectives: This systematic review is undertaken to examine the evidence from randomized controlled trials (RCTs) and observational studies to evaluate the effectiveness of SCS in post lumbar surgery syndrome and to demonstrate clinical and cost effectiveness.

Methods: Review of the literature was performed according to the Cochrane Musculoskeletal Review Group Criteria as utilized for interventional techniques for randomized trials and the Agency for Healthcare Research and Quality (AHRQ) criteria for observational studies.

The 5 levels of evidence were classified as Level I, II, or III with 3 subcategories in Level II based on the quality of evidence developed by the U.S. Preventive Services Task Force (USPSTF).

Data sources included relevant literature of the English language identified through searches of PubMed and EMBASE from 1966 to December 2008, and manual searches of bibliographies of known primary and review articles.

Outcome Measures: The primary outcome measure was pain relief (short-term relief $\leq$ one-year and long-term > one-year). Secondary outcome measures of improvement in functional status, psychological status, return to work, and reduction in opioid intake were utilized.

Results: The indicated evidence is Level II-1 or II-2 for long-term relief in managing patients with failed back surgery syndrome.

Limitations: The limitations of this review included the paucity and heterogeneity of the literature.

Conclusion: This systematic review evaluating the effectiveness of SCS in relieving chronic intractable pain of failed back surgery syndrome indicated the evidence to be Level II-1 or II-2 for clinical use on a long-term basis.

Key words: Chronic low back pain, neuropathic pain, failed back surgery syndrome, FBSS, post lumbar surgery syndrome, electrical stimulation, spinal cord stimulation

Pain Physician 2009; 12:379-397 


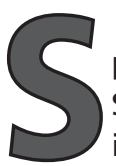
pinal cord stimulation (SCS) introduced by Shealy et al in 1967 (1), is primarily implanted in the United States for failed back surgery syndrome (FBSS) and complex regional pain syndromes (CRPS) (2-12). Medicare spending for in-patient back surgery more than doubled over the decade, with an increase for lumbar fusion of $500 \%$, from $\$ 75$ million to $\$ 482$ million, and lumbar fusion representing $47 \%$ of total spending for back surgery in 2003 in contrast to $14 \%$ in 1992 (13). In the year 2002, more than one million spinal procedures were performed in the United States with 400,000 cases being instrumented (13-19). Similarly, increases of $159 \%$ in spinal cord implants over a 10-year period from 1997 to 2006 have been reported in the Medicare population (2024). Management of post lumbar surgery syndrome with numerous modalities of treatments including interventional techniques, results in moderate improvement, yet leaves a proportion of patients in intractable pain $(6,25-35)$.

In the first decade after its introduction, SCS was extensively used and was claimed to have been applied indiscriminately to a diverse spectrum of pain diagnoses with poor follow-up of the patients leading to disrepute of this technology. During the past decade, there has been growing awareness that SCS might be a reasonably effective therapy for patients suffering from neuropathic pain for which there is no other alternative therapy (11). Multiple reasons described for the increased use of SCS include identification of relevant indications; improved design of electrodes, leads, and receivers/stimulators, resulting in improved success and reduction in incidence of reoperations for device failure; and introduction of the percutaneous electrode implantation facilitating trial stimulation $(11,36,37)$.

The first systematic review of the long-term benefits and risks of SCS for patients with FBSS was performed by Turner et al in 1995 (2). However, this review has been criticized for including observational studies and methodological flaws. Subsequently, Turner et al (7) updated their review in 2004 to include data from 7 new studies including randomized controlled trials (RCTs) for the assessment of effectiveness and 15 studies for the assessment of adverse effects. They concluded that methodologically robust studies are needed to establish the effectiveness of SCS. The only randomized trial found a statistically significant moderate effect on pain, but no notable improvement in function. Taylor et al (3) performed a systematic review and analysis of prognostic factors of SCS for chronic back, leg pain, and FBSS, including one RCT (38), one cohort study, and 72 case studies. They reported that there was evidence of substantial statistical heterogenicity in the level of pain relief following SCS reported across case series studies. They also reported there were 4 principal prognostic factors to be predictive of an increased level of pain relief, including poor study quality score, short follow-up duration, multi-center (versus single center) studies, and including only those patients with FBSS versus chronic back and leg pain. Overall, they reported $43 \%$ of patients with chronic back and leg pain/FBSS experienced one or more complications following a SCS implant, even though no major adverse events were reported. They concluded that despite an increase in the number of studies, the level of evidence for the efficacy of SCS in chronic back and leg pain secondary to FBSS remains "moderate." Taylor et al (8) in a 2006 systematic review and metaanalysis of SCS in refractory neuropathic back and leg pain secondary to FBSS and CRPS concluded that the use of SCS in patients with refractory neuropathic pain of FBSS was Grade B evidence. They also noted that SCS not only reduces pain, improves quality of life, reduces analgesic consumption, and allows some patients to return to work, with minimally significant adverse events, but may also result in significant cost savings over time. Cochrane review for SCS for chronic pain (11) published in 2007 included multiple conditions including multiple sclerosis, CRPS, phantom pain, diabetic neuropathy, and post herpetic neuralgia, in addition to FBSS. They included 2 RCTs with 81 patients in total $(39,40)$. They concluded that there is limited evidence in favor of SCS for FBSS and CRPS Type I and more trials are needed to confirm whether SCS is an effective treatment for certain types of chronic pain. In a reassessment of an evidence synthesis by the American College of Occupational and Environmental Medicine (ACOEM) guidelines Manchikanti et al (41) included 3 randomized trials $(39,40,42)$.

Cost-effectiveness of SCS also has been performed specifically in FBSS $(5,43)$. In a systematic review of the literature, Taylor et al (5) found initial health care acquisition costs were offset by a reduction in post implant health care resource demands and costs. Mean 5 -year costs were $\$ 29,123$ in the intervention group, compared to $\$ 38,029$ in the control group for FBSS Bala et al (43) performed a systematic review of the cost-effectiveness of SCS for patients with FBSS and showed that, in terms of cost-effectiveness, 3 studies 
met the inclusion criteria and offered the same conclusion and showed that, in terms of cost-effectiveness, SCS is more effective and less costly in the long-term, but there is an initial high cost associated with device implantation and maintenance. They also showed that SCS was effective in the treatment of FBSS in terms of pain reduction. Practice parameters for the use of SCS in the treatment of chronic neuropathic pain (12) provided a strength of recommendation of A for FBSS.

Thus, the discussion continues with claims of lack of evidence on the one hand and escalating increases in utilization on the other hand $(41,44-47)$. This systematic review is undertaken to examine the evidence from the available literature of the effectiveness of SCS in post lumbar surgery syndrome.

\section{Methods}

\section{Literature Search}

A comprehensive literature search was conducted which included search of databases including PubMed and EMBASE from 1966 through December 2008, Cochrane database, Clinical Trial Registry, systematic reviews, narrative reviews, and cross-references to reviews published in the English language.

The search strategy emphasized chronic low back and lower extremity pain with a focus on SCS. Search terminology included post laminectomy syndrome, post surgery syndrome, FBSS, arachnoiditis, chronic low back pain, neuropathic pain, SCS, dorsal column stimulation.

\section{Selection Criteria}

Types of participants considered are patients with chronic low back pain of post lumbar surgery syndrome of at least 12 months duration. Types of interventions included surgically implanted, as well as percutaneously implanted, monopolar or multipolar, single or multi-channel, and ramped or intermittent stimulation devices.

Exclusion criteria included any types of pain other than post lumbar surgery syndrome.

\section{Outcome Parameters}

The following outcome measures were of documented pain relief at various points in time, functional assessment, and other outcomes including psychological improvement, return to work, change in opioid intake, and cost effectiveness. The follow-up criteria are a minimum of one-year with appropriate outcome measures of at least pain relief and functional status.

\section{Review Criteria}

The review focused on randomized trials and observational studies and reports of complications. The population of interest was patients suffering with FBSS. All studies providing appropriate management with outcome evaluations of 12 months or longer and statistical evaluations were reviewed. Reports without appropriate diagnosis, book chapters, and case reports were excluded.

\section{Study Criteria}

Two physicians evaluated each study for the stated criteria and a third physician resolved any disagreements.

If there was a conflict of interest with the reviewed manuscripts with authorship or any other type of conflict, the involved authors did not review the manuscripts for quality assessment, clinical relevance, evidence synthesis, or grading of evidence.

\section{Methodologic Quality Assessment}

The quality of each individual article used in this analysis was assessed by modified Cochrane review criteria with weighted scores (48) for randomized trials and the Agency for Healthcare Research and Quality (AHRQ) criteria for assessment of observational studies (49) with consensus-based weighted scoring developed by the guidelines committee of the American Society of Interventional Pain Physicians (ASIPP) and utilized in multiple evaluations $(25,33,35,41,50-56)$.

Only the studies scoring at least 50 of 100 on weighted scoring criteria were utilized for analysis.

Observational studies were only included in the evidence synthesis if there were less than 4 randomized trials meeting the inclusion criteria.

\section{Clinical Relevance}

The clinical relevance of the included studies was evaluated according to 5 questions recommended by the Cochrane Back Review Group $(57,58)$.

Each question was scored positive (+) if the clinical relevance item was met, negative (-) if the item was not met, and unclear (?) if data were not available to answer the question.

In the recent Cochrane review of "Injection Therapy for Subacute and Chronic Low Back Pain" (57), the authors considered a $20 \%$ improvement in pain scores (59) and a 10\% improvement in functioning outcomes 
(60) to be clinically important. This study utilized stricter criteria than previous systematic reviews. We also utilized strict methodologic quality assessment criteria (57) for inclusion and up to one year as short-term relief with long-term relief as longer than one year. Observational studies were also included with scores of 50 or more on a scale of $0-100$ based on AHRQ criteria. This improves the generalizability of the systematic review as well as the intervention (61-65).

\section{Analysis of Evidence}

Qualities analysis was conducted using 5 levels of evidence, ranging from Level I to III with 3 subcategories in Level II, as illustrated in Table 1 (66).

\section{Recommendations}

Grading recommendations were based on Guyatt et al's criteria (67).

\section{Outcome of the Studies}

A study was judged to be positive if it was clinically relevant and effective, either with a placebo control or active comparator in randomized trials. This indicates that the difference in the effect for the primary outcome measure was statistically significant at the conventional $5 \%$ level. In a negative study, no difference between the study treatment and no improvement from baseline was reported. For observational studies, a study was judged to be positive if the intervention was effective, with outcomes reported at the reference point with positive or negative results.

Relief of 12 months or less was considered as short-term and relief of longer than 12 months was considered as long-term.

\section{Results}

A literature search was carried out for SCS as shown in Fig. 1.

Our search strategy yielded 6 randomized trials (38-40,68-70) and 25 observational studies (71-95) evaluating the effectiveness of SCS. In addition, 3 studies evaluated cost effectiveness (96-98).

\section{Randomized Trials}

\section{Methodologic Quality Assessment}

Of the 6 randomized trials, 2 met the inclusion criteria for methodological assessment and clinical relevance $(39,68)$. Two of the manuscripts $(38,42)$ were duplicates $(39,68)$. One study $(69)$ was a comparison of SCS electrode design, whereas the second study (70) was a study of SCS for axial low back pain comparing dual with single percutaneous electrodes. Both of them were of short-term follow-up, thus both studies were excluded from the methodologic quality assessment. Methodologic quality assessment criteria and clinical relevance criteria for randomized trials are illustrated in Tables 2 and 3.

The quality assessment criteria scores derived were 55 and 56 respectively for the randomized trials eligible to be included in the analysis $(39,68)$.

\section{Clinical Relevance Assessment}

Both studies met clinical relevance criteria $(39,68)$.

\section{Study Characteristics}

Kumar et al $(42,68)$ compared SCS with conventional medical management (CMM) in patients with neuropathic pain secondary to FBSS with predominant

Table 1. Quality of evidence developed by USPSTF.

\begin{tabular}{|c|l||}
\hline \hline I: & Evidence obtained from at least one properly randomized controlled trial \\
\hline II-1: & Evidence obtained from well-designed controlled trials without randomization \\
\hline II-2: & $\begin{array}{l}\text { Evidence obtained from well-designed cohort or case-control analytic studies, preferably from more than one center or research } \\
\text { group }\end{array}$ \\
\hline II-3: & $\begin{array}{l}\text { Evidence obtained from multiple time series with or without the intervention. Dramatic results in uncontrolled experiments (such } \\
\text { as the results of the introduction of penicillin treatment in the 1940s) could also be regarded as this type of evidence }\end{array}$ \\
\hline III: & Opinions of respected authorities, based on clinical experience descriptive studies and case reports or reports of expert committees \\
\hline
\end{tabular}

Adapted from the U.S. Preventive Services Task Force (USPSTF) (66). 


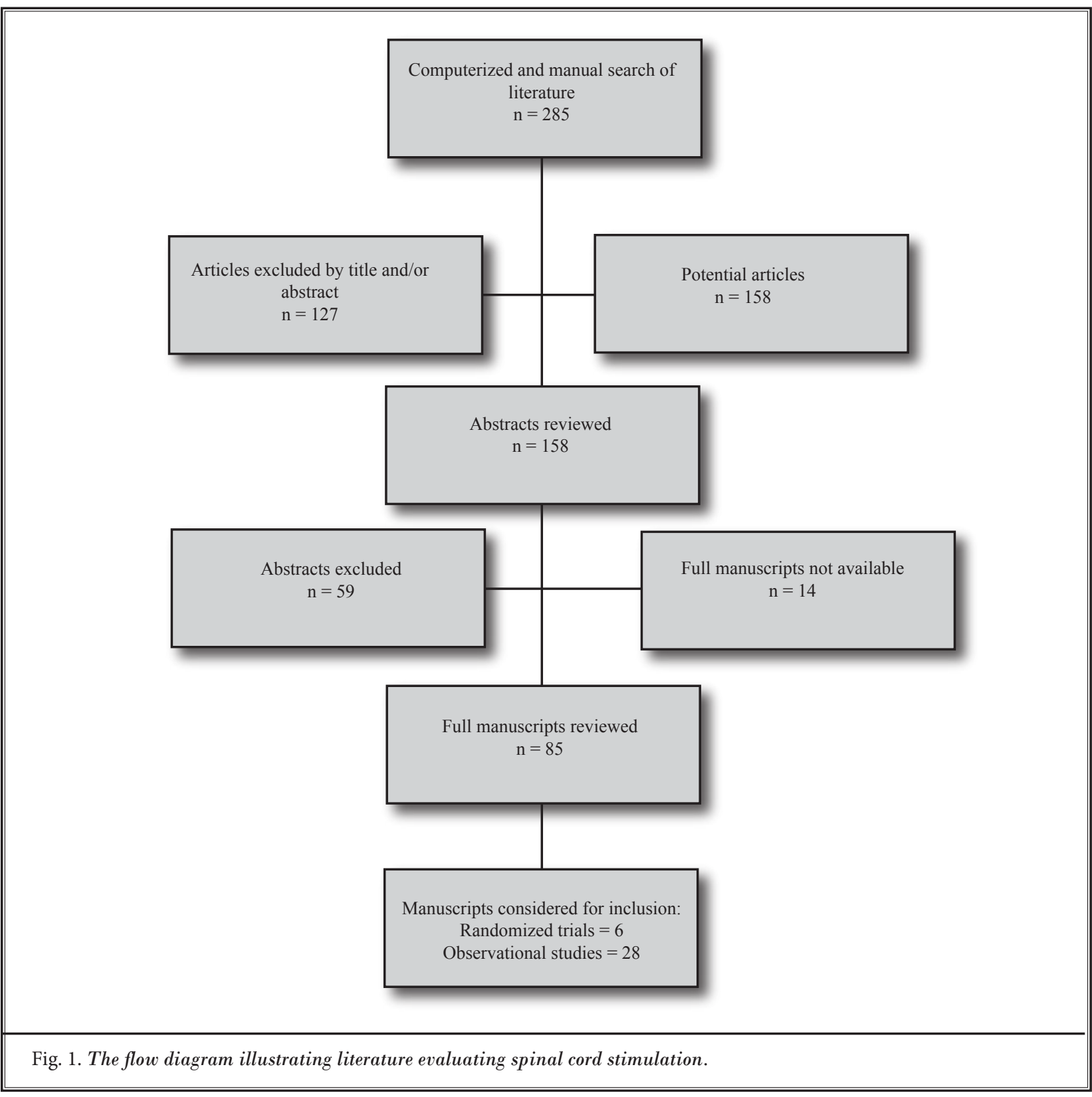

leg pain of neuropathic radicular origin. In both groups CMM was "actively managed." Of those who were randomized to medical management, by 12 months only $25 \%(16 / 48)$ remained in that arm, after 12 months, 28 elected to cross over to SCS. Five of those in the SCS group crossed over to the CMM group at 6 months, 4 because of inadequate pain relief. By 12 months, the protocol analysis showed $48 \%$ of the SCS group and $9 \%$ of the medical management group achieving at least $50 \%$ pain relief. By $24-$ month follow-up, 42 out of
52 randomized patients continuing SCS reported significantly improved leg pain relief, quality of life, and functional capacity; and 13 patients $(31 \%)$ required a device-related surgical revision (68). At 24 months, of 46 out of 52 patients randomized to SCS and 41 of the 48 patients randomized to $\mathrm{CMM}$ who were available, the primary outcome was achieved by $34(47 \%)$ out of 72 patients who received SCS as final treatment versus one (7\%) of 15 for CMM. The authors concluded that compared with the medical management group, the 
Table 2. Methodological assessment of randomized clinical trials evaluating spinal cord stimulation in post lumbar surgery syndrome.

\begin{tabular}{|c|c|c|c|c|}
\hline \multicolumn{2}{|c|}{ CRITERION } & $\begin{array}{l}\text { WEIGHTED SCORE } \\
\text { (points) }\end{array}$ & Kumar et al (68) & North et al (39) \\
\hline \multicolumn{5}{|c|}{ Study population } \\
\hline A & Homogeneity & 2 & 2 & 2 \\
\hline $\mathrm{B}$ & Comparability of relevant baseline characteristics & 5 & 4 & 2 \\
\hline $\mathrm{C}$ & Randomization procedure adequate & 4 & 4 & 4 \\
\hline $\mathrm{D}$ & Drop-outs described for each study group separately & 3 & 3 & 3 \\
\hline \multirow[t]{2}{*}{$\mathrm{E}$} & $\leq 20 \%$ loss for follow-up & 2 & 2 & - \\
\hline & $\leq 10 \%$ loss for follow-up & 2 & - & - \\
\hline \multirow[t]{2}{*}{$\mathrm{F}$} & $>50$ subject in the smallest group & 8 & - & - \\
\hline & $>100$ subjects in the smallest group & 9 & - & - \\
\hline \multicolumn{5}{|c|}{ Interventions } \\
\hline G & Interventions included in protocol and described & 10 & 10 & 10 \\
\hline $\mathrm{H}$ & Pragmatic study & 5 & 5 & 5 \\
\hline I & Co-interventions avoided or similar & 5 & - & - \\
\hline $\mathrm{J}$ & Placebo-controlled & 5 & - & - \\
\hline \multicolumn{5}{|c|}{ Effect } \\
\hline $\mathrm{K}$ & Patients blinded & 5 & - & - \\
\hline $\mathrm{L}$ & Outcome measures relevant & 10 & 10 & 10 \\
\hline M & Blinded outcome assessments & 10 & - & 10 \\
\hline $\mathrm{N}$ & Follow-up period adequate & 5 & 5 & 5 \\
\hline \multicolumn{5}{|c|}{ Data-presentation and analysis } \\
\hline $\mathrm{O}$ & Intention-to-treat analysis & 5 & 5 & - \\
\hline $\mathrm{P}$ & $\begin{array}{l}\text { Frequencies of most important outcomes presented for } \\
\text { each treatment group }\end{array}$ & 5 & 5 & 5 \\
\hline \multicolumn{2}{|c|}{ TOTAL SCORE } & 100 & 55 & 56 \\
\hline
\end{tabular}

Methodological criteria and scoring adapted from Koes BW et al. Efficacy of epidural steroid injections for low-back pain and sciatica: A systematic review of randomized clinical trials. Pain 1995; 63:279-288 (48).

Table 3. Clinical relevance of randomized clinical trials evaluating the effectiveness of spinal cord stimulation.

\begin{tabular}{|l|c|c||}
\hline & Kumar et al (68) & North et al (39) \\
\hline $\begin{array}{l}\text { A) Are the patients described in detail so that you can decide whether they are comparable to } \\
\text { those that you see in your practice? }\end{array}$ & + & + \\
\hline $\begin{array}{l}\text { B) Are the interventions and treatment settings described well enough so that you can provide the } \\
\text { same for your patients? }\end{array}$ & + & + \\
\hline C) Were all clinically relevant outcomes measured and reported? & + & + \\
\hline D) Is the size of the effect clinically important? & + & - \\
\hline E) Are the likely treatment benefits worth the potential harms? & $4 / 5$ & + \\
\hline TOTAL CRITERIA MET & + \\
\hline
\end{tabular}

+ = positive; - = negative

Scoring adapted from Staal JB et al. Injection therapy for subacute and chronic low-back pain. Cochrane Database Syst Rev 2008; 3:CD001824 (57). 
spinal cord group experienced improved leg and back pain relief, quality of life, and functional capacity, as well as greater treatment satisfaction. The compliance rate in conventional treatment was low $(33 \%)$, which raised questions by the authors of ACOEM guidelines (44). Medical management was criticized as being unstructured, with numerous potential confounders and utilization co-interventions (44). They also criticized the sharp reduction in the number who achieved the $50 \%$ pain relief target at 12 months, suggesting that the benefits, even if real, are not long-term. However, even at 24-month follow-up, 34 of 72 patients (47\%) who received SCS as their final treatment achieved the primary outcome compared to 1 of 15 or $7 \%$ for CMM $(P=0.02)$. Overall improvement in leg pain relief and improvement in functional capacity were more robust $(P=0.0001$ and $P=0.0002)$. Further, some of the criticisms related to inherent difficulties include lack of blinding which is difficult in SCS because of the paresthesia associated with treatment. The study did not blind outcome assessors and even though they reported that the groups were comparable, back pain scores in the control group were higher.

North et al (39) presented results of SCS versus repeated lumbosacral spine surgery for chronic pain in a RCT. Of the 99 patients from a consecutive series invited to participate in the study, 60 candidates consented to randomization and 50 proceeded to a treatment. The 39 patients who refused randomization chose to undergo reoperation. For an average of 3 years postoperatively, disinterested third party interviewers followed 50 patients selected for reoperation by standard criteria and randomized to SCS or reoperation. If the results of the randomized treatment were unsatisfactory, patients were allowed to cross over to the alternative. Success was based on self-reported pain relief and patient satisfaction. Among 45 patients $(90 \%)$ available for follow-up, SCS was more successful than reoperation (9 of 19 patients versus 3 of 26 patients, $P \leq 0.01$ ). Patients initially randomized to SCS were significantly less likely to cross over than were those randomized to reoperation ( 5 of 24 patients versus 14 of 26 patients, $P=0.02$ ). Patients randomized to reoperation required increased opiate analgesics significantly more often than those randomized to SCS ( $P$ $\leq 0.025$ ). However, other measures of activities of daily living and work status did not differ significantly. They concluded that SCS is more effective than reoperation as a treatment for persistent radicular pain after lumbosacral spine surgery, and in the great majority of patients, it obviates the need for reoperation. In summary, long-term success rates at $2.9 \pm 1.1$ years were for SCS, $47 \%$ versus reoperation $12 \%(P \leq 0.01)$. Some have criticized the study because reoperation is essentially a repeat of the same treatment, which in critics' opinions produced a potential bias in favor of the new treatment (44). However, long-term follow-up showed 15 of 29 in the successful group for SCS, while it was only 3 of 16 in the reoperation group. Further, the study was not blinded as blinding is difficult in SCS because of paresthesia associated with treatment. They used a disinterested third party for outcome assessment; this person was not blinded to treatment allocation. An additional limitation is that patients were randomized before the authorization from an insurance company was sought. As a result, 9 patients were not authorized by worker's compensation insurance to participate in the study and one other patient had a stroke; these 10 patients were excluded from the analysis. Moreover, it is not possible to assess the data reported from this study after a mean of 2.9 years as patients were allowed to crossover; which they did. Thus, groups assessed at the longest follow-up were no longer randomized groups. The comparability of the groups also has been questioned (43).

Both studies showed greater patient satisfaction with SCS treatment than with control treatment either in terms of satisfaction with pain relief and agreeing with the treatment or in terms of crossover to alternative treatment.

\section{Observational Studies}

Twenty-five observational studies (71-95) were considered for inclusion. Fifteen observational studies failed to meet inclusion criteria and therefore were excluded (80-83,85-95).

\section{Methodologic Quality Assessment}

The quality assessment criteria for observational studies are illustrated in Table 4 . Of the 10 studies meeting the quality assessment criteria $(71-79,84)$, the scores ranged from 37 to 62 with 9 of them meeting criteria for inclusion for the evidence synthesis.

\section{Study Characteristics}

Study characteristics are illustrated in Table 5 . These studies are not only observational, but met with multiple deficiencies. Of all the observational studies, only one study had methodologic quality scoring of higher than 60 (76). These studies only assist in form- 
Table 4. Illustration of methodologic assessment of observational studies of spinal cord stimulation.

\begin{tabular}{|c|c|c|c|c|c|c|c|c|c|c|c|}
\hline CRITERION & $\begin{array}{l}\text { Weighted } \\
\text { Score } \\
\text { (points) } \\
\end{array}$ & $\begin{array}{c}\text { Van } \\
\text { Buyten } \\
\text { et al } \\
(74) \\
\end{array}$ & $\begin{array}{c}\text { Kumar } \\
\text { and } \\
\text { Toth } \\
(71) \\
\end{array}$ & $\begin{array}{c}\text { De La } \\
\text { Porte and } \\
\text { Van de } \\
\text { Kelft (73) } \\
\end{array}$ & $\begin{array}{l}\text { Devulder } \\
\text { et al (72) }\end{array}$ & $\begin{array}{l}\text { Fiume } \\
\text { et al } \\
(75) \\
\end{array}$ & $\begin{array}{l}\text { North } \\
\text { et al } \\
(76) \\
\end{array}$ & $\begin{array}{c}\text { Dario } \\
(77)\end{array}$ & $\begin{array}{c}\text { De La } \\
\text { Porte } \\
\text { and } \\
\text { Siegfried } \\
(78) \\
\end{array}$ & $\begin{array}{c}\text { Burchiel } \\
\text { et al } \\
(79) \\
\end{array}$ & $\begin{array}{l}\text { Ohnmeiss } \\
\text { et al (84) }\end{array}$ \\
\hline 1. Study Question & 2 & 2 & 2 & 2 & 2 & 2 & 2 & 2 & 2 & 2 & 2 \\
\hline $\begin{array}{l}\text { - Clearly focused and } \\
\text { appropriate question }\end{array}$ & & & & & & & & & & & \\
\hline 2. Study Population & 8 & 5 & 5 & 5 & 5 & 5 & 5 & 5 & 5 & 5 & 5 \\
\hline $\begin{array}{l}\text { - Description of study } \\
\text { population }\end{array}$ & 5 & 5 & 5 & 5 & 5 & 5 & 5 & 5 & 5 & 5 & 5 \\
\hline - Sample size justification & 3 & - & - & - & - & - & - & - & - & - & - \\
\hline $\begin{array}{l}\text { 3. Comparability of } \\
\text { Subjects }\end{array}$ & 22 & 5 & 5 & 5 & 5 & 5 & 5 & 13 & 5 & 5 & 5 \\
\hline $\begin{array}{l}\text { - Specific inclusion/ } \\
\text { exclusion criteria for all } \\
\text { groups }\end{array}$ & 5 & 5 & 5 & 5 & 5 & 5 & 5 & 5 & 5 & 5 & 5 \\
\hline $\begin{array}{l}\text { - Criteria applied equally to } \\
\text { all groups }\end{array}$ & 3 & - & - & - & - & - & - & 3 & - & - & - \\
\hline $\begin{array}{l}\text { - Comparability of groups } \\
\text { at baseline with regard } \\
\text { to disease status and } \\
\text { prognostic factors }\end{array}$ & 3 & - & - & - & - & - & - & 3 & - & - & - \\
\hline $\begin{array}{l}\text { - Study groups comparable } \\
\text { to non-participants with } \\
\text { regard to confounding } \\
\text { factors }\end{array}$ & 3 & - & - & - & - & - & - & - & - & - & - \\
\hline $\begin{array}{l}\text { - Use of concurrent } \\
\text { controls }\end{array}$ & 5 & - & - & - & - & - & - & - & - & - & - \\
\hline $\begin{array}{l}\text { Comparability of follow- } \\
\text { up among groups at each } \\
\text { assessment }\end{array}$ & 3 & - & - & - & - & - & - & - & - & - & - \\
\hline 4. Exposure or Intervention & 11 & 7 & 8 & 8 & 8 & 7 & 8 & 11 & 8 & 8 & 8 \\
\hline $\begin{array}{l}\text { - Clear definition of } \\
\text { exposure }\end{array}$ & 5 & 5 & 5 & 5 & 5 & 5 & 5 & 5 & 5 & 5 & 5 \\
\hline $\begin{array}{l}\text { - Measurement method } \\
\text { standard, valid and } \\
\text { reliable }\end{array}$ & 3 & 2 & 3 & 3 & 3 & 2 & 3 & 3 & 3 & 3 & 3 \\
\hline $\begin{array}{l}\text { - Exposure measured } \\
\text { equally in all study groups }\end{array}$ & 3 & - & - & - & - & - & - & 3 & - & - & - \\
\hline 5. Outcome measures & 20 & 11 & 20 & 18 & 13 & 12 & 20 & 15 & 15 & 15 & 15 \\
\hline $\begin{array}{l}\text { - Primary/secondary } \\
\text { outcomes clearly defined }\end{array}$ & 5 & 2 & 5 & 3 & 5 & 3 & 5 & 5 & 5 & 5 & 5 \\
\hline $\begin{array}{l}\text { Outcomes assessed } \\
\text { blind to exposure or } \\
\text { intervention }\end{array}$ & 5 & 2 & 5 & 5 & - & 5 & 5 & - & - & - & - \\
\hline $\begin{array}{l}\text { - Method of outcome } \\
\text { assessment standard, } \\
\text { valid and reliable }\end{array}$ & 5 & 2 & 5 & 5 & 3 & 2 & 5 & 5 & 5 & 5 & 5 \\
\hline $\begin{array}{l}\text { - Length of follow-up } \\
\text { adequate for question }\end{array}$ & 5 & 5 & 5 & 5 & 5 & 2 & 5 & 5 & 5 & 5 & 5 \\
\hline 6. Statistical Analysis & 19 & 5 & - & - & 5 & - & 10 & - & - & 10 & 10 \\
\hline $\begin{array}{l}\text { - Statistical tests } \\
\text { appropriate }\end{array}$ & 5 & 5 & - & - & 5 & - & 5 & - & - & 5 & 5 \\
\hline
\end{tabular}


Spinal Cord Stimulation Systematic Review

Table 4 (cont.). Illustration of methodologic assessment of observational studies of spinal cord stimulation.

\begin{tabular}{|c|c|c|c|c|c|c|c|c|c|c|c|}
\hline CRITERION & $\begin{array}{l}\text { Weighted } \\
\text { Score } \\
\text { (points) }\end{array}$ & $\begin{array}{c}\text { Van } \\
\text { Buyten } \\
\text { et al } \\
(74) \\
\end{array}$ & $\begin{array}{c}\text { Kumar } \\
\text { and } \\
\text { Toth } \\
(71) \\
\end{array}$ & $\begin{array}{c}\text { De La } \\
\text { Porte and } \\
\text { Van de } \\
\text { Kelft (73) } \\
\end{array}$ & $\begin{array}{l}\text { Devulder } \\
\text { et al (72) }\end{array}$ & $\begin{array}{c}\text { Fiume } \\
\text { et al } \\
(75) \\
\end{array}$ & $\begin{array}{l}\text { North } \\
\text { et al } \\
(76) \\
\end{array}$ & $\begin{array}{c}\text { Dario } \\
(77)\end{array}$ & $\begin{array}{c}\text { De La } \\
\text { Porte } \\
\text { and } \\
\text { Siegfried } \\
\text { (78) } \\
\end{array}$ & $\begin{array}{c}\text { Burchiel } \\
\text { et al } \\
(79)\end{array}$ & $\begin{array}{l}\text { Ohnmeiss } \\
\text { et al (84) }\end{array}$ \\
\hline $\begin{array}{l}\text { Multiple comparisons } \\
\text { taken into consideration }\end{array}$ & 3 & - & - & - & - & - & 3 & - & - & 3 & 3 \\
\hline $\begin{array}{l}\text { - Modeling and } \\
\text { multivariate techniques } \\
\text { appropriate }\end{array}$ & 2 & - & - & - & - & - & 2 & - & - & 2 & 2 \\
\hline $\begin{array}{l}\text { - Power calculation } \\
\text { provided }\end{array}$ & 2 & - & - & - & - & - & - & - & - & - & - \\
\hline $\begin{array}{l}\text { - Assessment of } \\
\text { confounding }\end{array}$ & 5 & - & - & - & - & - & - & - & - & - & - \\
\hline $\begin{array}{l}\text { - Dose-response } \\
\text { assessment if appropriate }\end{array}$ & 2 & - & - & - & - & - & - & - & - & - & - \\
\hline 7. Results & 8 & 8 & 8 & 8 & 8 & 2 & 5 & 5 & 5 & 5 & 5 \\
\hline $\begin{array}{l}\text { Measure of effect for } \\
\text { outcomes and appropriate } \\
\text { measure of precision }\end{array}$ & 5 & 5 & 5 & 5 & 5 & 2 & 5 & 2 & 5 & 5 & 5 \\
\hline $\begin{array}{l}\text { - Adequacy of follow-up } \\
\text { for each study group }\end{array}$ & 3 & 3 & 3 & 3 & 3 & - & - & 3 & - & - & - \\
\hline 8. Discussion & 5 & 5 & 5 & 5 & 5 & 2 & 5 & 3 & 5 & 5 & 5 \\
\hline $\begin{array}{l}\text { Conclusions supported } \\
\text { by results with possible } \\
\text { biases and limitations } \\
\text { taken into consideration }\end{array}$ & & & & & & & & & & & \\
\hline 9. Funding or Sponsorship & 5 & 5 & 5 & 5 & 5 & 2 & 2 & 2 & 5 & 2 & 2 \\
\hline $\begin{array}{l}\text { - Type and sources of } \\
\text { support for study }\end{array}$ & & & & & & & & & & & \\
\hline TOTAL SCORE & 100 & 53 & 58 & 56 & 56 & 37 & 62 & 56 & 50 & 57 & 57 \\
\hline
\end{tabular}

Adapted and modified from West S et al. Systems to Rate the Strength of Scientific Evidence, Evidence Report, Technology Assessment No. 47. AHRQ Publication No. 02-E016 (49).

ing the conclusions regarding treatment effectiveness, and the results should be interpreted with caution keeping in mind their high risk of bias. Consequently, the results shown in these observational studies are more positive than the results from the RCTs. Partly, this is because the results in most cases are reported only for permanently implanted patients. In the studies that reported at least the number of patients who had an SCS trial, the percentage of patients who experienced failed SCS was over $47 \%$. Generally, reporting was inadequate which prevents an appropriate assessment of methodologic quality. Further, when the relevant information was reported, the quality of these reports was in general relatively poor, scoring less than 60 . As has been reported in systematic reviews and elsewhere, in accordance with current pain assess- ment standards, most observational reports showed pain relief using the threshold cutoff of $50 \%$ or more, even though they utilized a variety of methodologies. Some studies reported pain relief without reference to a specific cutoff figure using the wording such as poor, fair, good, or excellent. Some have equated good or excellent pain relief as the equivalent to the $50 \%$ or more cutoff. Consequently, significant heterogeneity was observed in the level of pain relief with SCS across studies. Pain relief was demonstrated in less than $60 \%$ of patients in 4 studies $(71,73,76,79)$, whereas in 5 studies the response was $60 \%$ of the patients or more showing improvement $(72,74,77,78,84)$.

Return to work was reported in $31 \%$ of the patients (74), $16 \%$ (73), and $25 \%$ (76), a $26 \%$ increase in working capacity (78) was reported, and $13 \%$ re- 
Table 5. Characteristics of observational studies of spinal cord stimulation.

\begin{tabular}{|c|c|c|c|c|c|}
\hline $\begin{array}{l}\text { Study/ } \\
\text { Methods }\end{array}$ & Participants & Intervention(s) & Outcome(s) & Result(s) & $\begin{array}{c}\text { Conclusion(s) } \\
\text { Positive }= \\
\text { relief }>12 \\
\text { months } \\
\end{array}$ \\
\hline $\begin{array}{l}\text { Van Buyten et } \\
\text { al (74) }\end{array}$ & $\begin{array}{l}254 \text { patients } \\
\text { Over a } 10 \text {-year period } \\
\text { in a single center, } 254 \\
\text { patients were subjected } \\
\text { to trial period of SCS } \\
\text { with an externalized } \\
\text { pulsed generator. Of } \\
\text { these, } 217 \text { of the patients } \\
\text { showed satisfactory } \\
\text { results justifying } \\
\text { permanent implantation } \\
\text { of the SCS system. The } \\
\text { results were available } \\
\text { to an independent } \\
\text { physician in } 153 \text { patients. }\end{array}$ & $\begin{array}{l}\text { SCS with } \\
\text { externalized pulse } \\
\text { generator }\end{array}$ & $\begin{array}{l}\text { McGill Pain } \\
\text { Questionnaire, VAS, } \\
\text { quality of life, sleep } \\
\text { disturbance, global } \\
\text { patient assessment, pain } \\
\text { medication intake and } \\
\text { complications. }\end{array}$ & $\begin{array}{l}68 \% \text { of the patients rated } \\
\text { the result of the treatment } \\
\text { as excellent to good after an } \\
\text { average follow-up of almost } 4 \\
\text { years. The resumption of work } \\
\text { by } 31 \% \text { of patients who had } \\
\text { been working before the onset } \\
\text { of pain supports these positive } \\
\text { findings. }\end{array}$ & Positive \\
\hline $\begin{array}{l}\text { Kumar and } \\
\text { Toth (71) }\end{array}$ & $\begin{array}{l}\text { Of the } 221 \text { patients } \\
\text { with SCS for post } \\
\text { laminectomy pain, } 182 \\
\text { patients were considered } \\
\text { for analysis of the } \\
\text { effectiveness of SCS in } \\
\text { post laminectomy pain, } \\
153 \text { men and } 29 \text { women } \\
\text { were included. }\end{array}$ & $\begin{array}{l}\text { All patients } \\
\text { underwent trial } \\
\text { stimulation of } \\
\text { 3-to 7-days. Of } \\
\text { the } 182 \text { patients } \\
\text { included in the } \\
\text { study, } 165 \text { patients } \\
\text { (91\%) experienced } \\
\text { satisfactory initial } \\
\text { pain relief and } \\
\text { had their systems } \\
\text { internalized. }\end{array}$ & 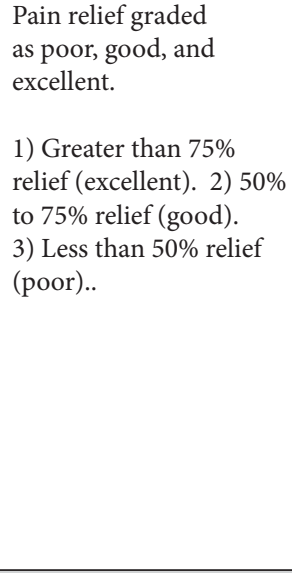 & $\begin{array}{l}\text { Minimum follow-up period was } \\
8 \text { months and the maximum } \\
\text { follow-up period was } 204 \\
\text { months. Average follow-up was } \\
8.8 \pm 4.5 \text { years. After an average } \\
8.8 \pm 4.5 \text { years of follow-up, } \\
87 \text { internalized patients (53\%) } \\
\text { continued to receive satisfactory } \\
\text { pain relief. Of the } 87 \text { patients } \\
\text { that were considered successful, } \\
44 \% \text { reported excellent pain } \\
\text { relief and } 56 \% \text { reported good } \\
\text { pain relief. Thus, out of the } 182 \\
\text { patients in this study } 48 \% \text { of } \\
\text { patients experienced } 50 \% \text { or } \\
\text { greater long-term relief with } \\
\text { SCS. }\end{array}$ & Negative \\
\hline $\begin{array}{l}\text { De La Porte } \\
\text { and Van de } \\
\text { Kelft (73) }\end{array}$ & $\begin{array}{l}78 \text { patients with } \\
\text { post laminectomy } \\
\text { syndrome underwent } \\
\text { trial stimulation, of } \\
\text { these, } 64 \text { underwent an } \\
\text { internalization of the } \\
\text { system and they were } \\
\text { followed every } 3 \text { months } \\
\text { for a mean follow-up } \\
\text { period of } 4 \text { years (range } \\
1-7 \text { years). }\end{array}$ & SCS & $\begin{array}{l}\text { Pain relief graded as } \\
\text { excellent, good, fair, } \\
\text { poor, worse. Excellent } \\
\text { with pain relief of } 75 \% \\
\text { to } 100 \% \text {. Good } 50 \% \text { to } \\
74 \% \text { pain relief. Fair } 25 \% \\
\text { to } 49 \% \text { pain relief. } 0 \% \text { to } \\
24 \% \text { poor pain relief. }\end{array}$ & $\begin{array}{l}\text { Thirty-seven or } 58 \% \text { of the } \\
\text { patients reported satisfactory } \\
\text { relief of good to excellent at } \\
\text { one-year. At final follow-up } 35 \\
\text { patients (58\%) continued to } \\
\text { experience at least } 50 \% \text { of pain } \\
\text { relief at the latest follow-up. } \\
\text { Fifty-eight patients ( } 90 \% \text { ) were } \\
\text { able to reduce their medication, } \\
39 \text { patients ( } 61 \% \text { ) increased. } \\
\text { Fifty-three patients ( } 83 \%) \\
\text { continued to use their device at } \\
\text { the latest follow-up }\end{array}$ & Positive. \\
\hline $\begin{array}{l}\text { Devulder et al } \\
\text { (72) }\end{array}$ & $\begin{array}{l}69 \text { patients with chronic } \\
\text { FBSS received SCS. All } \\
\text { patients underwent trial } \\
\text { stimulation over a period } \\
\text { of } 2 \text { weeks, however data } \\
\text { is not available on trial to } \\
\text { permanent stimulation. }\end{array}$ & SCS & $\begin{array}{l}\text { Pain relief, return to } \\
\text { work, concomitant use } \\
\text { of pain killing drugs. } \\
\text { Very good relief more } \\
\text { than } 80 \% \text { relief. Almost } \\
\text { very good pain relief, } \\
50 \% \text { to } 80 \% \text { relief. Good } \\
\text { relief } 50 \% \text {. Little relief } \\
30 \% \text { to } 50 \% . \text { Poor relief } \\
\text { less than } 30 \% \text {. }\end{array}$ & $\begin{array}{l}\text { Forty-three of } 69(77 \%) \\
\text { patients continued with the } \\
\text { therapy and obtained good pain } \\
\text { relief. Ten patients obtained } \\
\text { better pain relief than during } \\
\text { the trial procedure. Eleven } \\
\text { patients have returned to work. } \\
\text { The application of SCS cost on } \\
\text { an average } \$ 3,660 \text { per patient } \\
\text { per year. }\end{array}$ & Positive \\
\hline
\end{tabular}


Table 5 cont. Characteristics of observational studies of spinal cord stimulation.

\begin{tabular}{|c|c|c|c|c|c|}
\hline $\begin{array}{l}\text { Study/ } \\
\text { Methods }\end{array}$ & Participants & Intervention(s) & Outcome(s) & Result(s) & $\begin{array}{c}\text { Conclusion(s) } \\
\text { Positive = } \\
\text { relief }>12 \\
\text { months }\end{array}$ \\
\hline $\begin{array}{l}\text { North et al } \\
\text { (76) }\end{array}$ & $\begin{array}{l}\text { A series of } 50 \text { patients } \\
\text { with FBSS averaging } 3.1 \\
\text { previous operations, who } \\
\text { underwent spinal cord } \\
\text { stimulator implantation. }\end{array}$ & SCS & $\begin{array}{l}\text { Successful outcome } \\
\text { was defined as } 50 \% \\
\text { sustained relief of } \\
\text { pain and patient } \\
\text { satisfaction with the } \\
\text { result, improvement } \\
\text { in activities, return } \\
\text { to work, reduction or } \\
\text { elimination of analgesic } \\
\text { intake. }\end{array}$ & $\begin{array}{l}\text { Successful outcome was } \\
\text { recorded in } 53 \% \text { of the } \\
\text { patients at } 2.2 \text { years and in } \\
47 \% \text { of patients at } 5 \text { years } \\
\text { postoperatively. } 10 \text { of } 40(25 \%) \\
\text { patients who were disabled } \\
\text { preoperatively returned to work. } \\
\text { Improvements in activities of } \\
\text { daily living were recorded in } \\
\text { most patients for most activities. } \\
\text { Most patients reduced or } \\
\text { eliminated analgesic intake. }\end{array}$ & Positive \\
\hline Dario (77) & $\begin{array}{l}49 \text { patients were included } \\
\text { in the study from } 1992 \\
\text { to } 1997.44 \text { patients } \\
\text { with } 20 \text { patients treated } \\
\text { medically and } 24 \text { patients } \\
\text { who did not respond to } \\
\text { medical therapy, were } \\
\text { treated with SCS implant, } \\
\text { and } 5 \text { patients underwent } \\
\text { further spine surgery. }\end{array}$ & $\begin{array}{l}\text { 1) Medical } \\
\text { management with } \\
\text { other interventions; } \\
\text { 2) SCS; 3) Repeat } \\
\text { surgery }\end{array}$ & $\begin{array}{l}\text { Visual Analogue scale, } \\
\text { pain disability index } \\
\text { (PDI), Oswestry scales, } \\
\text { leg pain, back pain, work } \\
\text { status or daily activities, } \\
\text { drug side effects, and use } \\
\text { of analgesic medications. } \\
\text { Follow-up ranged from } \\
24 \text { to } 84 \text { months with a } \\
\text { mean of } 42 \text { months. }\end{array}$ & $\begin{array}{l}\text { All but } 2 \text { patients treated with } \\
\text { SCS demonstrated good results } \\
\text { for their leg pain (17 of } 24 \text { or } \\
71 \% \text { ); but not for back pain. } \\
40 \% \text { of the patients treated } \\
\text { medically demonstrated good } \\
\text { results on leg and low back } \\
\text { pain. In other cases, good } \\
\text { results were transitory and } \\
\text { several therapeutic courses } \\
\text { were necessary. }\end{array}$ & Positive \\
\hline $\begin{array}{l}\text { De La Porte } \\
\text { and Siegfried } \\
(78)\end{array}$ & $\begin{array}{l}94 \text { patients suffering } \\
\text { from low-back pain, with } \\
\text { or without spread into } \\
\text { the lower extremities. }\end{array}$ & SCS & $\begin{array}{l}\text { Working capacity, and } \\
\text { changes in medication, } \\
\text { subjective improvement }\end{array}$ & $\begin{array}{l}\text { The long-term results, based on a } \\
\text { four-year follow-up, reveal a } 60 \% \\
\text { subjective improvement of pain, } \\
\text { a } 40 \% \text { substantial reduction of } \\
\text { medication, and a } 26 \% \text { increase } \\
\text { in working capacity. }\end{array}$ & Positive \\
\hline $\begin{array}{l}\text { Burchiel et al } \\
\text { (79) }\end{array}$ & $\begin{array}{l}219 \text { patients were entered } \\
\text { at } 5 \text { centers throughout } \\
\text { the United States. } \\
45 \text { patients or } 64 \% \text { of the } \\
\text { sample included FBSS. }\end{array}$ & $\begin{array}{l}\text { One hundred } \\
\text { eighty-two patients } \\
\text { were implanted } \\
\text { with a permanent } \\
\text { stimulating system. } \\
\text { At the time of this } \\
\text { report, complete 1- } \\
\text { year follow-up data } \\
\text { were available on } \\
70 \text { patients, } 88 \% \text { of } \\
\text { whom reported pain } \\
\text { in the back or lower } \\
\text { extremities. }\end{array}$ & $\begin{array}{l}\text { The average pain } \\
\text { visual analogue scale, } \\
\text { the McGill Pain } \\
\text { Questionnaire, the } \\
\text { Oswestry Disability } \\
\text { Questionnaire, the } \\
\text { Sickness Impact Profile, } \\
\text { and the Back Depression } \\
\text { Inventory. Overall } \\
\text { success of the therapy } \\
\text { was defined as at least } \\
50 \% \text { pain relief and } \\
\text { patient assessment of } \\
\text { the procedure as fully or } \\
\text { partially beneficial and } \\
\text { worthwhile. }\end{array}$ & $\begin{array}{l}\text { All pain and quality-of-life } \\
\text { measures showed statistically } \\
\text { significant improvement during } \\
\text { the treatment year. Therapy } \\
\text { was shown in } 55 \% \text { of patients } \\
\text { on whom 1-year follow-up } \\
\text { was available. Complications } \\
\text { requiring surgical intervention } \\
\text { were reported by } 17 \% \text { ( } 12 \text { of } \\
70 \text { ) of patients. Medication } \\
\text { usage and work status were not } \\
\text { changed significantly. }\end{array}$ & Positive \\
\hline $\begin{array}{l}\text { Ohnmeiss et } \\
\text { al (84) }\end{array}$ & $\begin{array}{l}40 \text { patients with } \\
\text { intractable leg pain with } \\
\text { FBSS. }\end{array}$ & SCS & $\begin{array}{l}\text { Sickness Impact Profile, } \\
\text { Visual Analogue scale } \\
\text { scores, pain status, } \\
\text { walking, and overall } \\
\text { lifestyle changes. } \\
\\
\text { Primary data } \\
\text { collection periods were } \\
\text { preoperative, } 6 \text { week } \\
\text { after, and } 12 \text { - and } 24 \\
\text { month follow-up. }\end{array}$ & $\begin{array}{l}\text { Significant improvements were } \\
\text { shown in leg pain, sickness } \\
\text { impact profile, walking } \\
\text { capacity, overall lifestyle, and } \\
\text { narcotic intake at } 12 \text { - and } 24 \text { - } \\
\text { month follow-up in } 70 \% \text { of the } \\
\text { patients. }\end{array}$ & Positive \\
\hline
\end{tabular}


ported entry into gainful employment (72), whereas one study (80) reported no change in the work status and the others did not report on this variable.

Opioid consumption was assessed across studies using a variety of definitions. Overall, 4 studies reported reduction in opioid intake $(73,76,78,84)$ and in one study (79) there was no change.

\section{Cost-Effectiveness:}

Cost-effectiveness was evaluated in 2 systematic reviews $(5,43)$ and 3 studies $(96-98)$ yielding positive results. Manca et al (96) in a prospective, randomized, controlled, multicenter study of patients with FBSS (PROCESS) trial in evaluation of quality of life, resource consumption, and cost of SCS versus CMM in neuropathic pain patients with FBSS showed that the 6-month mean total health care cost in the SCS group (CAN\$19,486; $€ 12,653$ ) was significantly higher than in the CMM group (CAN\$3,994; €2,594), with a mean adjusted difference of CAN\$15,395 (€9997) $(P \leq 0.001)$. However, the gain in health-related quality of life (HRQoL) with SCS over the same period of time was markedly greater in the SCS group, with a mean EuroQol-5D (EQ-5D) score difference of $0.25(P \leq 0.001)$ and $0.21(P \leq 0.001)$, respectively at 3 and 6 months after adjusting for baseline variables. They concluded that the addition of SCS to CMM in patients with neuropathic leg and back pain results in higher costs to the health system, but also generates important improvements in patients' functional and health status over the same period.

Kumar et al (98) showed the mean cost for SCS therapy over 5 years of CAN\$29,123 (inflation-adjusted CAN\$30,852) in 2007 equivalent to US $\$ 24,799$ and patient cost of CAN $\$ 41,964$ or US $\$ 33,722$ inflation adjusted for 2007 for conventional pain therapy. During the first 2.5 years, the cost for SCS was higher than conventional pain therapy owing to the initial high cost of implantable devices. After this period, however, the cost for SCS remained significantly lower than that for conventional pain therapy, whereas quality of life results showed a $27 \%$ improvement for the SCS group compared with a $12 \%$ improvement for the conventional pain therapy group. Sixty percent of the SCS patients reported being very satisfied with therapy, whereas $28 \%$ were satisfied and $12 \%$ were unsure. In contrast, $15 \%$ of the SCS group (9 patients) returned to work, whereas none of the conventional pain therapy group did, which was attributed to superior pain control and lower drug intake. They also showed that the lifespan of the electrode and the battery life of the pulse generator improved by $25 \%$. The payoff period would decrease from 2.5 years to 2.3 years. Finally the authors concluded that despite the initial high cost, SCS is a cost-effective strategy in that it leads to significant cost savings and increased quality of life in the long-term. Consequently, it is hypothesized that if a societal perspective were considered, SCS would be more cost-effective as more people return to work compared with those treated with conventional pain therapy.

North et al (97) performed cost effectiveness and cost utility analysis based on a randomized, controlled trial (39). The data for the first 42 patients was collected by a disinterested third party in a randomized, controlled, crossover trial. With a 3.1 year follow-up, 13 of 21 patients $(62 \%)$ crossed to reoperation versus 5 of 19 patients $(26 \%)$ that crossed to SCS $(P \leq 0.025)$. The mean cost per success was US $\$ 117,901$ for crossovers to SCS. No crossovers to reoperation achieved success despite a mean per-patient expenditure of US $\$ 260,584$. The mean per-patient cost was US $\$ 31,530$ for SCS versus US $\$ 38,160$ for reoperation (intention to treat), US $\$ 48,357$ for SCS versus US $\$ 105,928$ for reoperation (treated as intended), and US\$34,371 for SCS versus US $\$ 36,341$ for reoperation (final treatment). SCS was dominant (more effective and less expensive) in the incremental cost-effectiveness ratios and incremental cost-utility ratios. A bootstrapped simulation for incremental costs and quality-adjusted life years confirmed SCS's dominance, with approximately $72 \%$ of the cost results occurring below U.S. policy makers' "maximum willingness to pay" threshold. The authors concluded that SCS was less expensive and more effective than reoperation in selected FBSS patients and should be the initial therapy of choice compared to reoperation. Thus, SCS is most cost-effective when patients forego repeat operation and finally, if SCS should fail, reoperation is unlikely to succeed.

\section{Effectiveness}

Of the 2 randomized trials evaluating SCS, both showed positive results for short- and long-term relief $(39,68)$. Of the 9 observational studies meeting the inclusion criteria with methodologic quality assessment of 50 or higher, all of them showed positive results for short- and long-term relief, except for Kumar and Toth (71). 
Spinal Cord Stimulation Systematic Review

Table 6. Results of published studies of effectiveness of spinal cord stimulation in post lumbar surgery syndrome.

\begin{tabular}{|c|c|c|c|c|c|c|c|}
\hline \multirow[b]{2}{*}{ Study } & \multirow{2}{*}{$\begin{array}{c}\text { Study } \\
\text { Characteristics }\end{array}$} & \multirow{2}{*}{$\begin{array}{l}\text { Methodological } \\
\text { Quality Scoring }\end{array}$} & \multirow[b]{2}{*}{ Patients } & \multicolumn{2}{|c|}{ Pain Relief } & \multicolumn{2}{|c|}{ Results } \\
\hline & & & & $\leq 12 \operatorname{mos}$ & $>12$ mos. & $\begin{array}{l}\text { Short-term } \\
\leq 12 \text { mos. }\end{array}$ & $\begin{array}{c}\text { Long-term } \\
>12 \text { mos. }\end{array}$ \\
\hline Kumar et al (68) & RA & 55 & $\begin{array}{c}\mathrm{SCS}=52 \\
\mathrm{CMM}=48\end{array}$ & $48 \%$ vs $9 \%$ & $58 \%$ vs $17 \%$ & $\mathrm{P}$ & $\mathrm{P}$ \\
\hline North et al (39) & RA & 56 & $\begin{array}{c}\text { SCS }=24 \\
\text { Reoperation }=26\end{array}$ & $\begin{array}{c}\text { SCS } 9 / 19 \\
\text { Reoperation } \\
3 / 26 \\
\end{array}$ & $\begin{array}{c}\text { SCS } 9 / 19 \\
\text { Reoperation } \\
3 / 26 \\
\end{array}$ & $\mathrm{P}$ & $\mathrm{P}$ \\
\hline $\begin{array}{l}\text { Van Buyten et al } \\
\text { (74) }\end{array}$ & $\mathrm{O}$ & 53 & 254 & - & $68 \%$ & $\mathrm{P}$ & $\mathrm{P}$ \\
\hline $\begin{array}{l}\text { Kumar and Toth } \\
\text { (71) }\end{array}$ & $\mathrm{O}$ & 58 & 182 & - & $48 \%$ & $\mathrm{P}$ & $\mathrm{N}$ \\
\hline $\begin{array}{l}\text { De La Porte and } \\
\text { Van de Kelft (73) }\end{array}$ & $\mathrm{O}$ & 56 & 78 & - & $58 \%$ & $\mathrm{P}$ & $\mathrm{P}$ \\
\hline Devulder et al (72) & $\mathrm{O}$ & 56 & 69 & - & $77 \%$ & $\mathrm{P}$ & $\mathrm{P}$ \\
\hline North et al (76) & $\mathrm{O}$ & 62 & 50 & - & $53 \%$ & $\mathrm{P}$ & $\mathrm{P}$ \\
\hline Dario (77) & $\mathrm{O}$ & 56 & 49 & - & $71 \%$ & $\mathrm{P}$ & $\mathrm{P}$ \\
\hline $\begin{array}{l}\text { De La Porte and } \\
\text { Siegfried (78) }\end{array}$ & $\mathrm{O}$ & 50 & 94 & - & $60 \%$ & $\mathrm{P}$ & $\mathrm{P}$ \\
\hline Burchiel et al (79) & $\mathrm{O}$ & 57 & 219 & - & $55 \%$ & $\mathrm{P}$ & $\mathrm{P}$ \\
\hline Ohnmeiss et al (84) & $\mathrm{O}$ & 57 & 40 & - & $70 \%$ & $\mathrm{P}$ & $\mathrm{P}$ \\
\hline
\end{tabular}

$R A=$ randomized $; \mathrm{O}=$ observational; $\mathrm{SCS}=$ spinal cord stimulation; $\mathrm{CMM}=$ conventional medical management; $;$ vs = versus; $P=$ positive

Table 6 illustrates the results of effectiveness studies for SCS.

\section{Level of Evidence}

The indicated evidence for SCS is Level II-1 or II-2 for long-term relief in managing patients with FBSS.

\section{Recommendations}

Based on Guyatt et al's criteria (67), the recommendation for SCS is $1 \mathrm{~B}$ or $1 \mathrm{C} /$ strong recommendation with a caveat that the may change when higher quality evidence becomes available.

\section{Discussion}

This systematic review evaluating the effectiveness of SCS in relieving chronic intractable pain of post lumbar surgery syndrome indicated the level of evidence of II-1 or II-2 with $1 \mathrm{~B}$ or $1 \mathrm{C} /$ strong recommendation for clinical use on a long-term basis. This assessment included 2 randomized trials $(39,68)$ and 10 observational studies $(71-79,84)$ meeting stringent inclusion and methodologic quality assessment criteria.

The previous systematic reviews of SCS for FBSS identified multiple studies and provided variable evidence. In fact, the results of this review are similar to 
the previous evaluations with most of the studies included being the same. In this systematic review we were able to identify only one study by Kumar et al (42) which was included in the reassessment of evidence synthesis of ACOEM guidelines (41), but not in other studies evaluating the effectiveness of SCS. The study is limited by only one additional randomized trial with a total of 2 randomized trials for a procedure which involves escalating use and cost to the health care system in the United States. Consequently, this review may be criticized for using observational studies, however, the evidence is obtained from randomized trials and the addition of observational studies has not contaminated the evidence synthesis, but only increased the strengths of the analysis. The advantages and disadvantages of observational studies, randomized trials, and systematic reviews in pragmatic trials have been well described (61-65).

SCS or neurostimulation has been used to treat chronic intractable pain for 40 years by stimulating nerve fibers in the spinal cord. The resulting impulses in the fibers may inhibit the conduction of pain signals to the brain according to the pain gate theory proposed by Melzack and Wall in 1965 (99) and the sensation of pain is thus blocked. While SCS may reduce pain, it will not eliminate it as it masks the sensation of pain by producing tingling sensations or numbness. Consequently, the sympatholytic effect of SCS is one of its most obvious and interesting of the therapeutic properties considered in managing neuropathic pain secondary to FBSS and other conditions. A retrospective study by Hord et al (100) found that patients with CRPS who responded to smpathetic nervous blocks tended to do better with SCE than those with sympathetically independent neuropathic pain. Yet, no deleterious acute cardiovascular effects were demonstrated (101). SCS is applied through the electrical generator that delivers pulses by means of electrodes placed in the epidural space adjacent to a targeted spinal cord area presumed to be causing the pain. The leads containing electrodes may be implanted by laminectomy or percutaneously. Further, the number and type of leads (unipolar, bipolar, or multipolar) and the parameters of stimulation (amplitude pulse wide electrode sensation) may vary depending on the nerve roots involved and the intensity of the pain being experienced by the patient. An implanted or external battery supplies the power through an external radio-frequency transmitter; however, both sources of power are equipped with a computerized telemetry system that allows transcutaneous programming of the specific pattern of stimulation.

FBSS, defined as persistent back and/ or leg pain after spine surgery, is a growing phenomenon in the U.S., where the likelihood that a person with back pain will undergo operative therapy far exceeds the rest of the world (102). Also known as postlaminectomy syndrome, this umbrella term overlies a constellation of different symptoms and etiologies, the latter of which includes recurrent herniation, arachnoiditis, instability, epidural fibrosis, spinal stenosis, traumatic neuritis (battered root syndrome), juxtafusional discogenic pain, sacroiliac joint pain, and many others (13-19,103108). Since a significant percentage of these patients experience some form of neuropathic pain, and the success rate of repeat back surgery declines in parallel with the number of reoperations, many of these individuals may be good candidates for SCS. Although recent advances in SCS technology have improved coverage in patients with axial spine pain using dual electrodes $(109,110)$, individuals with predominantly neuropathic extremity pain are still widely acknowledged to be the best candidates for this treatment (108).

In 1983, De Le Porte and Siegfried (78) described the role of SCS in managing lumbosacral spinal fibrosis, also better known as arachnoiditis. The first report of arachnoiditis as a pathological process was described in 1903 (111). Subsequently, Mendel and Adler (112) renamed the condition "meningitis serosa spinalis." Over the years others have referred to inflammation and scarring of the arachnoid lining by a variety of different terms such as "chronic spinal meningitis" (113), "adhesive spinal arachnoiditis" (114), "meningitis serosa circumscripta" (115), and "spinal meningitides with radiculomyelopathy" (116). The first publication implicating disc surgery as a cause of arachnoiditis dates back to 1951 (117). Since then, "arachnoiditis" or "epidural arachnoiditis" has generally been used to describe the persistence of back pain after spine surgery in the absence of recurrent arachnoiditis. In carefully selected patients, refractory to conventional modalities, SCS is considered to be the treament of choice for postsurgical arachnoiditis.

Currently, the selection protocols for SCS implantation stipulate a screening period using temporary percutaneous placement of leads and an external generator (11). Medicare regulations use the following criteria to determine whether or not a candidate is suitable for SCS (118). Adapted from a sample policy from Trailblazer Health Enterprises, LLC: 
- To treat chronic pain caused by documented lumbosacral arachnoiditis that has not responded to medical management.

- To treat intractable pain caused by nerve root injuries, including those associated with post surgery syndrome (FBSS).

- The implantation of the stimulator is used only as a last late resort (if not a last resort).

- Other treatment modalities (pharmacological, surgical, physical, or psychological therapies) have not proved to be satisfactory or are judged unsuitable or contraindicated for the given patients.

- Patient has undergone careful physical and psychological screening, evaluation, and diagnosis by a multidisciplinary team prior to implantation. All facilities, equipment, and personnel required for the proper diagnosis, treatment, training, and follow-up must be available.

- Demonstration of pain relief with a temporarily implanted electrode precedes permanent implantation.

Practice parameters for the use of SCS in neuropathic pain have also described selection criteria, relative contraindications, and screening procedures (2). Most of these guidelines consider a 3- to 8-day trial period adequate to simulate the anticipated response to the definitive procedure and offer meaningful prognostic information as to whether SCS will succeed or fail. After the trial period the electrode should be rountinely explanted, so that patient and physican expectation bias do not skew interpretation of the screening trial. A successful screening trial results in at least $50 \%$ patient-reported pain relief both at rest and in the face of provocative physical activity, along with stable or reduced analgesic consumption and patient satisfaction. If adequate coverage does not occur during the screening trial, a repeat trial may be considered with different lead placement and settings.

Whereas the exact mechanism(s) by which SCS exerts its analgesic effects remain poorly understood, one likely explanation involves the inhibition of pain transmission in the dorsal horn of the spinal cord
$(36,119,120)$. For reasons that also elude current understanding, SCS seems to be more effective in treating neuropathic pain than pain resulting from ongoing tissue damage (i.e. nociceptive pain). Estimates regarding the prevalence of neuropathic pain in subjects with chronic back pain generally range between $10 \%$ to $19 \%$ $(121,122)$ though this percentage is considerably higher in those who have been treated with prior surgery.

The cost-effectiveness analysis in this review augers favorably for the use of SCS in patients with FBSS. However, more evidence is still needed to deterine at which point in the treatment continuum SCS should be considered, who are the best candidates for this treatment, and to further refine the optimal stimulation parameters.

SCS is not a risk-free endeavor. Taylor et al (3) reported that $43 \%$ of patients with chronic back and leg pain/FBSS experienced one or more complications with SCS, with the majority of these due to electrode or lead problems $(27 \%)$. Infections $(6 \%)$, generator problems $(6 \%)$, extension cable problems $(10 \%)$, and other issues, such as cerebrospinal fluid leaks $(7 \%)$, accounted for most of the remainder. On the positive side, no neurologic-related complications were reported in this systematic review. Recently, a case report was published describing a patient who experienced acute renal failure during a trial of SCS (123).

\section{Conclusion}

The results of this systematic review evaluating SCS in FBSS indicates a level of evidence of II-1 or II2 with a $1 \mathrm{~B}$ or $1 \mathrm{C} /$ strong recommendation for clinical use on a long-term basis.

\section{Acknowledgments}

The authors wish to thank the editorial board of Pain Physician, for review and criticism in improving the manuscript; Sekar Edem for assistance in search of literature; and Tonie M. Hatton and Diane E. Neihoff, transcriptionists (Pain Management Center of Paducah), for their assistance in the preparation of this manuscript. 


\section{References}

1. Shealy CN, Mortimer JT, Reswick JB. Electrical inhibition of pain by stimulation of the dorsal columns: Preliminary clinical report. Anesth Analg 1967; 46:489-491.

2. Turner JA, Loeser JD, Bell KG. Spinal cord stimulation for chronic low back pain. A systematic literature synthesis. Neurosurgery 1995; 37:1088-1096.

3. Taylor RS, Van Buyten JP, Buchser E. Spinal cord stimulation for chronic back and leg pain and failed back surgery syndrome : A systematic review and analysis of prognostic factors. Spine 2005; 30:152-160.

4. Airaksinen O, Brox JI, Cedraschi C, Hildebrandt J, Klaber-Moffett J, Kovacs F, Mannion AF, Reis S, Staal JB, Ursin H, Zanoli G. Chapter 4: European guidelines for the management of chronic nonspecific low back pain. Eur Spine J 2006; 15:S192-S300.

5. Taylor RS, Taylor RJ, Van Buyten JP, Buchser E, North R, Bayliss S. The cost effectiveness of spinal cord stimulation in the treatment of pain: A systematic review of the literature. J Pain Symptom Manage 2004; 27:370-378.

6. Boswell MV, Trescot AM, Datta S, Schultz DM, Hansen HC, Abdi S, Sehgal N, Shah RV, Singh V, Benyamin RM, Patel VB, Buenaventura RM, Colson JD, Cordner HJ, Epter RS, Jasper JF, Dunbar EE, Atluri SL, Bowman RC, Deer TR, Swicegood JR, Staats PS, Smith HS, Burton AW, Kloth DS, Giordano J, Manchikanti L. Interventional techniques: Evidencebased practice guidelines in the management of chronic spinal pain. Pain Physician 2007; 10:7-111.

7. Turner J, Loeser J, Deyo R, Sanders SB. Spinal cord stimulation for patients with failed back surgery syndrome or complex regional pain syndrome: A systemic review of effectiveness and complications. Pain 2004; 108:137-147.

8. Taylor RS. Spinal cord stimulation in complex regional pain syndrome and refractory neuropathic back and leg pain/FBSS: Results of a systematic review and meta-analysis. J Pain Symptom Manage 2006; 31:S13-S19.

9. Taylor RS, Van Buyten JP, Buchser E. Spinal cord stimulation for complex regional pain syndrome: A systematic review of the clinical and cost-effectiveness literature and assessment of prognostic factors. Eur J Pain 2006; 10:91-101.
10. Cameron T. Safety and efficacy of spinal cord stimulation for the treatment of chronic pain: A 20-year literature review. J Neurosurg 2004; 100:S254-S67.

11. Mailis-Gagnon A, Furlan AD, Sandoval JA, Taylor R. Spinal cord stimulation for chronic pain. Cochrane Database Syst Rev 2004; 3:CDo03783.

12. North R, Shipley J, Prager J, Barolat G, Barulich M, Bedder M, Calodney A, Daniels A, Deer T, DeLeon O, Drees S, Fautdch $M$, Fehrenbach W, Hernandez J, Kloth D, Krames ES, Lubenow T, North R, Osenbach R, Panchal SJ, Sitzman T, Staats P, Tremmel J, Wetzel T. Practice parameters for the use of spinal cord stimulation in the treatment of chronic neuropathic pain. Pain Med 2007; 8: S200-S275.

13. Lieberman IH. Disc bulge bubble: Spine economics 101. Spine J 2004; 4:609613.

14. Wenger DR. Spine surgery at a crossroads: Does economic growth threaten our professionalism? Spine 2007; 32:2158-2165.

15. Eisner W. Spinal fusion: CMS says "show us the evidence in November." Orthopedics This Week, July 26, 2006; www. ryortho.com/newsletters/volume2/issue24/07-25-06

16. Deyo RA, Nachemson A, Mirza SK. Spinal fusion surgery - The case for restraint. N Engl / Med 2004; 350:722726.

17. Deyo RA, Mirza SK. Trends and variations in the use of spine surgery. Clin Orthop Relat Res 2006; 443:139-146.

18. McCrory DC, Turner DA, Patwardhan MB, Richardson WL. DRAFT Spinal Fusion for Degenerative Disc Disease Affecting the Lumbar Spine. Agency for Healthcare Research and Quality. Duke Evidence-Based Practice Center. November 1, 2006.

www.cms.hhs.gov/determinationprocess/downloads/id41ta.pdf

19. Brox JI, Sørensen R, Friis A, Nygaard $\varnothing$, Indahl A, Keller A, Ingebrigtsen T, Eriksen HR, Holm I, Koller AK, Riise R, Reikerås 0 . Randomized clinical trial of lumbar instrumented fusion and cognitive intervention and exercises in patients with chronic low back pain and disc degeneration. Spine 2003; 28:1913-1921.

20. Manchikanti L, Hirsch JA. Issues in health care: Interventional pain man- agement at the crossroads. Health policy update. Pain Physician 2007; 10:261-284.

21. Manchikanti L, Boswell MV. Interventional techniques in ambulatory surgical centers: A look at the new payment system. Pain Physician 2007; 10:627650.

22. Manchikanti L, Giordano J. Physician payment 2008 for interventionalists: Current state of health care policy. Pain Physician 2007; 10:607-626.

23. Manchikanti L, Singh V, Pampati V, Smith HS, Hirsch J. Analysis of growth in interventional techniques in managing chronic pain in Medicare population: A 10-year evaluation from 1997 to 2006. Pain Physician 2009; 12:9-34.

24. Specialty Utilization data files from CMS: www.cms.hhs.gov

25. Conn A, Buenaventura RM, Datta S, Abdi S, Diwan S. Systematic review of caudal epidural injections in the management of chronic low back pain. Pain Physician 2009; 12:109-135.

26. Manchikanti L, Singh V, Cash KA, Pampati V, Datta S. Preliminary results of randomized, equivalence trial of fluoroscopic caudal epidural injections in managing chronic low back pain: Part 3. Post surgery syndrome. Pain Physician 2008; 11:817-831.

27. Manchikanti L, Cash KA, McManus CD, Pampati V, Abdi S. Preliminary results of randomized, equivalence trial of fluoroscopic caudal epidural injections in managing chronic low back pain: Part 4. Spinal stenosis. Pain Physician 2008; 11:833-848.

28. Abdi S, Datta S, Trescot AM, Schultz DM, Adlaka R, Atluri SL, Smith HS, Manchikanti L. Epidural steroids in the management of chronic spinal pain: A systematic review. Pain Physician 2007; 10:185-212.

29. Trescot AM, Chopra P, Abdi S, Datta S, Schultz DM. Systematic review of effectiveness and complications of adhesiolysis in the management of chronic spinal pain: An update. Pain Physician 2007; 10:129-146.

30. Manchikanti L, Boswell MV, Rivera JJ, Pampati V, Damron KS, McManus CD, Brandon DE, Wilson SR. A randomized, controlled trial of spinal endoscopic adhesiolysis in chronic refractory low back and lower extremity pain. BMC Anesthesiol 2005; 5:10. 
31. Manchikanti L, Rivera JJ, Pampati V, Damron KS, McManus CD, Brandon $D E$, Wilson SR. One day lumbar epidural adhesiolysis and hypertonic saline neurolysis in treatment of chronic low back pain: A randomized, double-blind trial. Pain Physician 2004; 7:177-186.

32. Heavner JE, Racz GB, Raj P. Percutaneous epidural neuroplasty. Prospective evaluation of $0.9 \% \mathrm{NaCl}$ versus $10 \%$ $\mathrm{NaCl}$ with or without hyaluronidase. Reg Anesth Pain Med 1999; 24:202207.

33. Epter RS, Helm S, Hayek SM, Benyamin RM, Smith HS, Abdi S. Systematic Review of percutaneous adhesiolysis and management of chronic low back pain in post lumbar surgery syndrome. Pain Physician 2009; 12:361-378.

34. Manchikanti L, Saini B, Singh V. Spinal endoscopy and lysis of epidural adhesions in the management of chronic low back pain. Pain Physician 2001; 4:240-265.

35. Hayek SM, Helm S, Benyamin RM, Singh V, Bryce DA, Smith HS. Effectiveness of spinal endoscopic adhesiolysis in post lumbar surgery syndrome: A systematic review. Pain Physician 2009; 12:419-435.

36. Meyerson BA, Linderoth B. Mechanisms of spinal cord stimulation in neuropathic pain. Neurol Res 2000; 22:285-292.

37. Barolat G, Sharan AD. Future trends in spinal cord stimulation. Neurol Res 2000; 22:279-284.

38. North RB, Kidd DH, Lee MS, Piantodosi S. Spinal cord stimulation versus reoperation for the failed back surgery syndrome: A prospective, randomized study design. Sterotact Funct Neurosurg 1994; 62:267-272.

39. North RB, Kidd DH, Farrokhi F, Piantadosi SA. Spinal cord stimulation versus repeated lumbosacral spine surgery for chronic pain: A randomized, controlled trial. Neurosurgery 2005; 56:98-107.

40. Kemler MA, Barendse GA, van Kleef $M$, de Vet HC, Rijks CP, Furnee CA, van den Wildenberg FA. Spinal cord stimulation in patients with chronic reflex sympathetic dystrophy. N Engl I Med 2000; 343:618-624.

41. Manchikanti L, Singh V, Derby R, Schultz DM, Benyamin RM, Prager JP, Hirsch JA. Reassessment of evidence synthesis of occupational medicine practice guidelines for interventional pain man- agement. Pain Physician 2008; 11:393482.

42. Kumar K, Taylor RS, Jacques L, Eldabe $\mathrm{S}$, Meglio M, Molet J, Thomson S, O'Callaghan J, Eisenberg E, Milbouw G, Buchser E, Fortini G, Richardson J, North RB. Spinal cord stimulation versus conventional medical management for neuropathic pain: A multicentre randomised controlled trial in patients with failed back surgery syndrome. Pain 2007; 132:179-188.

43. Bala MM, Riemsma RP, Nixon J, Kleijnen J. Systematic review of the (cost-) effectiveness of spinal cord stimulation for people with failed back surgery syndrome. Clin J Pain 2008; 24:757-758.

44. American College of Occupational and Environmental Medicine (ACOEM). Low Back Disorders Chapter. In Occupational Medicine Practice Guidelines: Evaluation and Management of Common Health Problems and Functional Recovery of Workers, Second Edition. American College of Occupational and Environmental Medicine, Elk Grove Village, 2007.

45. American College of Occupational and Environmental Medicine (ACOEM). Chronic Pain Chapter (revised 2008). In: Occupational Medicine Practice Guidelines: Evaluation and Management of Common Health Problems and Functional Recovery of Workers, Second Edition. American College of Occupational and Environmental Medicine, Elk Grove Village, Epublished August 14, 2008.

46. Manchikanti L, Singh V, Derby R, Helm $S$, Trescot AM, Staats PS, Prager JP, Hirsch JA. Review of occupational medicine practice guidelines for interventional pain management and potential implications. Pain Physician 2008; 11:271-289.

47. Manchikanti L, Singh V, Helm S, Trescot AM, Hirsch JA. A critical appraisal of 2007 American College of Occupational and Environmental Medicine (ACO$E M)$ practice guidelines for interventional pain management: An independent review utilizing AGREE, AMA, IOM, and other criteria. Pain Physician 2008; 11:291-310.

48. Koes BW, Scholten RJ, Mens JMA, Bouter LM. Efficacy of epidural steroid injections for low-back pain and sciatica: A systematic review of randomized clinical trials. Pain 1995; 63:279-288.

49. West S, King V, Carey TS, Lohr KN, McK- oy N, Sutton SF, Lux L. Systems to Rate the Strength of Scientific Evidence, Evidence Report, Technology Assessment No. 47. AHRQ Publication No. 02E016. Rockville, MD: Agency for Healthcare Research and Quality, 2002. www. thecre.com/pdf/ahrq-system-strength. pdf

50. Datta S, Lee M, Falco FJE, Bryce DA, Hayek SM. Systematic assessment of diagnostic accuracy and therapeutic utility of lumbar facet joint interventions. Pain Physician 2009; 12:437460.

51. Falco FJE, Erhart S, Wargo BW, Bryce DA, Atluri S, Datta S, Hayek SM. Systematic review of diagnostic utility and therapeutic effectiveness of cervical facet joint interventions. Pain Physician 2009; 12:323-344.

52. Buenaventura RM, Datta S, Abdi S, Smith HS. Systematic review of therapeutic lumbar transforaminal epidural steroid injections. Pain Physician 2009; 12:233-251.

53. Patel VB, Manchikanti L, Singh V, Schultz DM, Hayek SM, Smith HS. Systematic review of intrathecal infusion systems for long-term management of chronic non-cancer pain. Pain Physician 2009; 12:345-360.

54. Helm S, Hayek S, Benyamin RM, Manchikanti L. Systematic review of the effectiveness of thermal annular procedures in treating discogenic low back pain. Pain Physician 2009; 12:207-232.

55. Rupert MP, Lee M, Manchikanti L, Datta S, Cohen SP. Evaluation of sacroiliac joint interventions: A systematic appraisal of the literature. Pain Physician 2009; 12:399-418.

56. Atluri S, Datta S, Falco FJ, Lee M. Systematic review of diagnostic utility and therapeutic effectiveness of thoracic facet joint interventions. Pain Physician 2008; 11:611-629.

57. Staal JB, de Bie R, de Vet HC, Hildebrandt J, Nelemans P. Injection therapy for subacute and chronic low-back pain. Cochrane Database Syst Rev 2008; 3:CDoo1824.

58. van Tulder $M$, Furlan $A$, Bombardier C, Bouter L, Editorial Board of the Cochrane Collaboration Back Review Group. Updated method guidelines for systematic reviews in the Cochrane Collaboration Back Review Group. Spine 2003; 28:1290-1299. 
59. Salaffi F, Stancati A, Silvestri CA, Ciapetti A, Grassi W. Minimal clinically important changes in chronic musculoskeletal pain intensity measured on a numerical rating scale. Eur J Pain 2004; 8:283-291.

6o. Bombardier C. Outcome assessments in the evaluation of treatment of spinal disorders: Summary and general recommendations. Spine 2000; 25:31003103.

61. Manchikanti L, Boswell MV, Giordano J. Evidence-based interventional pain management: Principles, problems, potential, and applications. Pain Physician 2007; 10:329-356.

62. Manchikanti L. Evidence-based medicine, systematic reviews, and guidelines in interventional pain management: Part 1: Introduction and general considerations. Pain Physician 2008; 11:161-186.

63. Manchikanti L, Hirsch JA, Smith HS. Evidence-based medicine, systematic reviews, and guidelines in interventional pain management: Part 2: Randomized controlled trials. Pain Physician 2008; 11:717-773.

64. Manchikanti L, Benyamin R, Helm S, Hirsch JA. Evidence-based medicine, systematic reviews, and guidelines in interventional pain management: Part 3: Systematic reviews and meta-analysis of randomized trials. Pain Physician 2009; 12:35-72.

65. Manchikanti L, Singh V, Smith HS, Hirsch JA. Evidence-based medicine, systematic reviews, and guidelines in interventional pain management: Part 4: Observational studies. Pain Physician 2009; 12:73-108.

66. Berg AO, Allan JD. Introducing the third U.S. Preventive Services Task Force. Am J Prev Med 2001; 20:S3-S4.

67. Guyatt G, Gutterman D, Baumann MH, Addrizzo-Harris D, Hylek EM, Phillips B, Raskob G, Lewis SZ, Schünemann $\mathrm{H}$. Grading strength of recommendations and quality of evidence in clinical guidelines. Report from an American College of Chest Physicians Task Force. Chest 2006; 129:174-181.

68. Kumar K, Taylor RS, Jacques L, Eldabe S, Meglio M, Molet J, Thomson S, O'Callaghan J, Eisenberg E, Milbouw G, Buchser E, Fortini G, Richardson J, North RB. The effects of spinal cord stimulation in neuropathic pain are sustained: A 24-month follow-up of the prospective randomized controlled multicenter trial of the effectiveness of spinal cord stimulation. Neurosurgery 2008; 63:762-770.

69. North RB, Kidd DH, Petrucci L, Dorsi MJ. Spinal cord stimulation electrode design: A prospective, randomized, controlled trial comparing percutaneous with laminectomy electrodes: Part II clinical outcomes. Neurosurgery 2005; 57:990-995.

70. North RB, Kidd DH, Olin J, Sieracki JM, Farrokhi F, Petrucci L, Cutchis PN. Spinal cord stimulation for axial low back pain: A prospective, controlled trial comparing dual with single percutaneous electrodes. Spine 2005; 30:14121418.

71. Kumar K, Toth C. The role of spinal cord stimulation in the treatment of chronic pain postlaminectomy. Curr Pain Headache Rep 1998; 2:85-92.

72. Devulder J, De Laat M, Van Bastelaere M, Rolly G. Spinal cord stimulation: A valuable treatment for chronic failed back surgery patients. J Pain Symptom Manage 1997; 13:296-301.

73. De La Porte C, Van de Kelft E. Spinal cord stimulation in failed back surgery syndrome. Pain 1993; 52:55-61.

74. Van Buyten JP, Van Zundert J, Vueghs P, Vanduffel L. Efficacy of spinal cord stimulation: 10 years of experience in a pain centre in Belgium. EurJ Pain 2001; 5:299-307.

75. Fiume D, Sherkat S, Callovini GM, Parziale G, Gazzeri G. Treatment of the failed back surgery syndrome due to lumbo-sacral epidural fibrosis. Acta Neurochir Suppl 1995; 64:116-118.

76. North RB, Ewend MG, Lawton MT, Kidd $\mathrm{DH}$, Piantadosi S. failed back surgery syndrome: 5-year follow-up after spinal cord stimulator implantation. Neurosurgery 1991; 28:692-699.

77. Dario A. Treatment of failed back surgery syndrome. Neuromodulation 2001; 4:105-110.

78. De La Porte C, Siegfried J. Lumbosacral spinal fibrosis (spinal arachnoiditis). Its diagnosis and treatment by spinal cord stimulation. Spine 1983; 8:593603.

79. Burchiel KJ, Anderson VC, Brown FD, Fessler RG, Friedman WA, Pelofsky S, Weiner RL, Oakley J, Shatin D. Prospective, multicenter study of spinal cord stimulation for relief of chronic back and extremity pain. Spine 1996; 21:2786-2794.

8o. Kay AD, McIntyre MD, Macrae WA, Var- ma TR. Spinal cord stimulation--a longterm evaluation in patients with chronic pain. Br J Neurosurg 2001; 15:335341.

81. Kavar B, Rosenfeld JV, Hutchinson A. The efficacy of spinal cord stimulation for chronic pain. J Clin Neurosci 2000; 7:409-413.

82. North RB, Campbell JN, James CS, Conover-Walker MK, Wang $\mathrm{H}$, Piantadosi S, Rybock JD, Long DM. failed back surgery syndrome: 5 -year followup in 102 patients undergoing repeated operation. Neurosurgery 1991; 28:685690.

83. Oakley JC, Weiner RL. Spinal cord stimulation for complex regional pain syndrome: A prospective study of 19 patients at two centers. Neuromodulation 1999; 2:47-50.

84. Ohnmeiss DD, Rashbaum RF, Bogdanffy GM. Prospective outcome evaluation of spinal cord stimulation in patients with intractable leg pain. Spine 1996; 21:1344-1350.

85. Sanchez-Ledesma MJ, Garcia-March G, Diaz-Cascajo P, Gomez-Moreta J, Broseta J. Spinal cord stimulation in deafferentation pain. Stereotact Funct Neurosurg 1989; 53:40-45.

86. Simpson BA. Spinal cord stimulation in 60 cases of intractable pain. J Neurol Neurosurg Psychiatry 1991; 54:196199.

87. Van de Kelft E, De La Porte C. Long-term pain relief during spinal cord stimulation. The effect of patient selection. Qual Life Res 1994; 3:21-27.

88. Villavicencio AT, Leveque JC, Rubin R, Bulsara K, Gorecki JP. Laminectomy versus percutaneous electrode placement for spinal cord stimulation. Neurosurgery 2000; 46:399-406.

89. Wester K. Dorsal column stimulation in pain treatment. Acta Neurol Scand 1987; 75:151-155.

90. Kupers RC, Van den Oever R, Van Houdenhove B, Vanmechelen W, Hepp B, Nuttin B, Gybels JM. Spinal cord stimulation in Belgium: A nation-wide survey on the incidence, indications and therapeutic efficacy by the health insurer. Pain 1994; 56:211-216.

91. Van Buyten JP. Neurostimulation for chronic neuropathic back pain in failed back surgery syndrome. J Pain Symptom Manage 2006; 31:S25-S29.

92. Buvanendran A, Lubenow TJ. Efficacy of transverse tripolar spinal cord stimulator for the relief of chronic low back 
pain from failed back surgery. Pain Physician 2008; 11:333-338.

93. Atallah J, Armah FA, Wong D, Weis PA, Fahy BG. Use of spinal cord stimulator for treatment of lumbar radiculopathy in a patient with severe kyphoscoliosis. Pain Physician 2008; 11:555-559.

94. de Vos CC, Rajan V, Steenbergen W, van der Aa HE, Buschman HP. Effect and safety of spinal cord stimulation for treatment of chronic pain caused by diabetic neuropathy. J Diabetes Complications 2009; 23:40-45.

95. Slavin KV, Burchiel KJ, Anderson VC, Cooke B. Efficacy of transverse tripolar stimulation for relief of chronic low back pain: Results of a single center. Stereotact Funct Neurosurg 1999; 73:126-130.

96. Manca A, Kumar K, Taylor RS, Jacques L, Eldabe S, Meglio M, Molet J, Thomson S, O'Callaghan J, Eisenberg E, Milbouw G, Buchser E, Fortini G, Richardson J, Taylor RJ, Goeree R, Sculpher MJ. Quality of life, resource consumption and costs of spinal cord stimulation versus conventional medical management in neuropathic pain patients with failed back surgery syndrome (PROCESS trial). Eur J Pain 2008; 12:10471058.

97. North RB, Kidd D, Shipley J, Taylor RS. Spinal cord stimulation versus reoperation for failed back surgery syndrome: A cost effectiveness and cost utility analysis based on a randomized, controlled trial. Neurosurgery 2007; 61:361-368.

98. Kumar K, Malik S, Demeria D. Treatment of chronic pain with spinal cord stimulation versus alternative therapies: Cost-effectiveness analysis. $\mathrm{Neu}$ rosurgery 2002; 51:106-115.

99. Melzack R, Wall PD. Pain mechanisms: A new theory. Science 1965; 150:971979.

100. Hord ED, Cohen SP, Cosgrove GR, Ahmed SU, Vallejo R, Change Y, Stojanovic MP. The predictive value of sympathetic block for the success of spinal cord stimulation. Neurosurgery 2003; 53:626-633.
101. Schultz DM, Musley S, Beltrand P, Christensen J, Euler D, Warman E. Acute cardiovascular effects of epidural spinal cord stimulation. Pain Physician 2007; 10:677-685.

102. Cherkin DC, Deyo RA, Loeser JD, Bush T, Waddell G. An international comparison of back surgery rates. Spine 1994; 19:1201-1206.

103. Slipman CW, Shin CH, Patel RK, Isaac Z, Huston CW, Lipetz JS, Lenrow DA, Braverman DL, Vresilovic EJ Jr. Etiologies of failed back surgery syndrome. Pain Med 2002; 3:200-21; discussion 214-217.

104. Long DM, Filtzer DL, BenDebba M, Hender NH. Clinical features of the failedback syndrome. J Neurosurg 1988; 69:61-71.

105. Waguespack A., Schofferman J. Slosar P, Reynolds J. Etiology of long-term failures of lumbar spine surgery. Pain Med. 2002; 3:18-22.

106. Schofferman J, Reynolds J, Herzog R, Covington E, Dreyfuss P, O'Neill C. Failed back surgery: Etiology and diagnostic evaluation. Spine J 2003; 3:400403.

107. Waguespack A, Schofferman J, Slosar P, Reynolds J. Etiology of long-term failures of lumbar spine surgery. Pain Med 2002; 3:18-22.

108. Dworkin RH, Backonja N, Rowbotham $M C$, Allen RR, Argoff CR, Bennett GJ, Bushnell MC, Farrar JT, Galer BS, Haythornthwaite JA, Hewitt DJ, Loeser JD, Max MB, Saltarelli M, Schmader KE, Stein C, Thompson D, Turk DC, Wallace MS, Watkins LR, Weinstein SM. Advances in neuropathic pain: Diagnosis, mechanism and treatment recommendations. Arch Neurol 2003; 60:15241534.

109. North RB, Kidd DH, Olin J, Sieracki JM, Farrokhi F, Petrucci L, Cutchis PN. Spinal cord stimulation for axial low back pain: a prospective, controlled trial comparing dual with single percutaneous electrodes. Spine 2005; 30:14121418.

110. Ohnmeiss DD, Rashbaum RF. Patient satisfaction with spinal cord stimulation for predominant complaints of chronic, intractable low back pain. Spine J; 1:358-363.

111. Spiller W, Musser J, Martin E. A case of intradural spinal cyst with operation and recovery. University Penn Med Bull 1903; 16:27-31.

112. Mendel K, Adler S. Zur kentnis der meningitis serosa spinalis. Berl Klin Wochenschr 1908; 45:1596-1602.

113. Horsley V. Chronic spinal meningitis: Its differential diagnosis and surgical treatment. Br Med J 1909; 1:513-517.

114. Stookey B. Adhesive spinal arachnoiditis simulating spinal cord tumor. Arch Neurol Psychiatr 1927; 17:151-178.

115. Elkington J. Meningitis serosa circumscripta spinalis (spinal arachnoiditis). Brain 1936; 59:181-203.

116. Wadia N, Dastur D. Spinal meningitides with radiculomyelopathy. J Neurol Sci Part 1 1969; 8:239-260, J Neurol Sci Part 2 1969; 8:261-297.

117. Smolik E, Nash F. Lumbar spinal arachnoiditis: A complication of the intervertebral disc operation. Ann Surg 1951; 133:490-495.

118. LCD for Spinal Cord Stimulation (Dorsal Column Stimulation) - 4S - 146AB-R2 (L26741). Effective Date 12/18/2008.

119. Woolf CJ, Doubell TP. The pathophysiology of chronic pain--increased sensitivity to low threshold A beta-fibre inputs. Curr Opin Neurobiol 1994; 4:525-534.

120. Devor M. Relation of foraminal (lateral) stenosis to radicular pain. Am J Neuroradiol 1996; 17:1615-1617.

121. Taylor RS. Epidemiology of refractory neuropathic pain. Pain Pract 2006; 6:22-26.

122. Freynhagen R, Baron R, Gockel U, Tölle TR. painDETECT: a new screening questionnaire to identify neuropathic components in patients with back pain. Curr Med Res Opin. 2006; 22:19111920.

123. Larkin TM, Dragovich A, Cohen SP. Acute renal failure during a trial of spinal cord stimulation: Theories as to a possible connection. Pain Physician 2008; 11:681-686. 
